\title{
KEKUATAN PEMBUKTIAN AKTA NOTARIAL DALAM PENYELESAIAN PERKARA JUAL BELI TANAH (STUDI PUTUSAN NO. 124 PK/PDT/2015)
}

\section{Edmond Putra}

(Mahasiswa Program S1 Fakultas Hukum Universitas Tarumanagara)

(E-mail: edmund.lee95@gmail.com)

\section{Hasni}

(Corresponding Author)

(Dosen Hukum Agraria, Filsafat Hukum, Etika Profesi, dan Hukum Lingkungan Fakultas Hukum Universitas Tarumanagara, Meraih Sarjana Hukum dari Fakultas Hukum Universitas Atma Jaya dan Universitas Krisnadwipayana, Magister Hukum dari Fakultas Hukum Universitas Indonesia, Doktor Hukum dari Fakultas Hukum Trisakti)

\begin{abstract}
Agrarian law in the broad sense is the entire rules of law both written and unwritten governing the earth, water and within certain limits also space and natural wealth contained therein.as well as in a process of buying and selling land, the parties will certainly first make an agreement between the parties before the buying and selling of land. in this case the binding sale and purchase agreement, which serves as a proof tool at the time of the litigants in court. but in this case despite the existence of such strong and perfect evidence, the judge does not decide the case carefully and fairly, the reason is that one of the parties in this case feels aggrieved by the verdict granted by the judge, for what has been written in binding agreements of sale and purchase and addendum are not used as a basis by the judge in deciding the case. then it is with the writing of this journal, it is expected that this journal can be the aspirations and opinions in examining a civil case, so it is for the future if there is a similar case can be used as a reference for the enforcer the law to be more careful and study the case being handled it, the purpose is to avoid the occurrence of judges who are less aware of the knowledge of the case being handled, so that it affects the quality of decisions made by it.
\end{abstract}

Keywords : Agrarian, Notarial Deed 


\section{PENDAHULUAN}

\section{A. Latar Belakang}

Manusia pada dasarnya merupakan makhluk hidup yang tidak dapat tinggal sendiri tanpa adanya sosialisasi dengan makhluk lainnya, karena pada dasarnya manusia merupakan makhluk social yang tidak dapat bertahan hidup tanpa bantuan dari manusia lainnya. Dan juga dengan adanya interaksi antara manusia yang satu dengan manusia yang lainnya maka tidak dapat lepas pula dari aspek hukum, ekonomi, sosial dan budaya. Hubungan hukum di dalam kehidupan manusia tidak terlepas dari interaksinya dengan segi ekonomi, seiring pertumbuhan ekonomi yang pesat dan kebutuhan manusia yang semakin meningkat, beragam, dan banyak jenisnya terutama di era globalisasi ini jelas lebih kompleks dan lebih terperinci hubungan antara manusia dalam kegiatan ekonomi, dimana pada zaman dahulu kegiatan ekonomi yang dimaksud sangat sederhana seperti barter dan jual beli, akan tetapi pada kenyataannya sifat manusia yang tidak pernah puas melahirkan kegiatan ekonomi lainnya yang lebih kompleks. Kegiatan ekonomi yang dimaksud terdiri dari berbagai macam jenis seperti jual-beli, sewa-menyewa, kredit, sewa-pakai, sewa-beli dan masih banyak lagi, seluruh kegiatan ini diatur di dalam suatu sistem hukum guna untuk menjaga ke eksistensian dari kegiatan ekonomi tersebut, kegiatan ekonomi ini akan menimbulkan suatu hubungan hukum yang pada akhirnya melahirkan suatu perjanjian antara pihak-pihak yang setuju untuk melakukan perjanjian itu.

Hubungan hukum dengan ekonomi bukan hubungan satu arah, tetapi hubungan timbal balik dan saling mempengaruhi, kegiatan ekonomi yang tidak didukung oleh hukum akan mengakibatkan terjadinya kekacauan, sebab apabila para pelaku ekonomi dalam mengejar keuntungan tidak dilandasi dengan norma hukum, maka akan menimbulkan kerugian salah satu pihak dalam melakukan kegiatan ekonomi. Membahas tentang perjanjian, salah satu perjanjian yang paling kerap terjadi dalam kehidupan manusia ini yaitu perjanjian mengenai jual beli tanah. Jika dilihat dari undang-undang nomor 5 tahun 1960 tanah dalam pengertian Yuridis adalah permukaan bumi, sedangkan hak atas tanah adalah hak atas sebagian tertentu 
permukaan bumi, yang berbatas berdimensi dua dengan ukuran panjang dan lebar ${ }^{1}$. Dengan adanya jual beli atas tanah pastinya juga menimbulkan perjanjian bagi kedua belah pihak tersebut yang biasanya bisa berupa Akta Perjanjian Pengikatan Jual Beli ataupun langsung diadakan Akta Jual Beli tanpa adanya Akta Perjanjian Pengikatan Jual beli dahulu. Fungsi dari akta PPAT yang dibuat tersebut adalah sebagai bukti, bahwa benar telah dilakukan perbuatan hukum yang bersangkutan. Dan karena perbuatan hukum itu sifatnya tunai, sekaligus membuktikan berpindahnya hak atas tanah yang bersangkutan dengan penerima hak. Karena tata usaha PPAT sifatnya tertutup untuk umum, pembuktian mengenai berpindahnya hak tersebut berlakunya terbatas pada para pihak yang melakukan perbuatan hukum yang bersangkutan ${ }^{2}$.

Pembuktian pada dasarnya merupakan hal yang wajib dalam pemeriksaan suatu perkara, khususnya perkara yang didalam nya terdapat sengketa atau contentiosa. Jika dalam pemeriksaan suatu sengketa perdata, para pihak berbeda pendapat atau pendirian dan masing-masing ingin meneguhkan dalil-dalilnya, maka pada saat itulah dibutuhkan pembuktian untuk meyakinkan hakim pihak mana yang benar atau mempunyai hak dan pihak mana yang salah atau tidak mempunyai hak.

Pembuktian sebagai sebuah proses mengandung beberapa unsur yang berkaitan satu sama lain. Mengidentifikasi unsur-unsur pembuktian dapat dilakukan dengan menganalisis definisi dari pembuktian yang telah dikemukakan sebelumnya. Dari analisis terhadap definisi pembuktian, maka Unsur-unsur dalam pembuktian adalah ${ }^{3}$ :

\section{Para Pihak (Penggugat dan Tergugat, Pemohon)}

Unsur pertama dan utama dalam pembuktian adalah adanya para pihak (penggugat dan tergugat) yang bersengketa dalam suatu perkara; pemohon dalam perkara permohonan. Para pihak ini yang memili kewenangan menentukannya. Luasnya

\footnotetext{
${ }^{1}$ Boedi Harsono, Hukum Agraria Indonesia, Cetakan ke-1. (Jakarta: Penerbit Universitas Trisakti, 2013), hal. 18.

${ }^{2}$ Ibid., hal. 514.

${ }^{3}$ Yahya harahap, Hukum Acara Perdata tentang Gugatan, Persidangan, Penyitaan, Pembuktian, dan Putusan Pengadilan, Jakarta: Sinar Grafika, 2010.
} 
gugatan (onderwerp van den eis), bukan hakim. Luasnya gugatan yang ditentukan oleh para pihak ditentukan dalam proses jawab-menjawab. Sejak pembacaan gugatan hingga duplik, hakim akan mengidentifikasi pokok permasalahan yang selanjutnya wajib dibuktikan oleh para pihak.

\section{Alat-alat bukti}

Unsur selanjutnya dalam pembuktian adalah alat-alat bukti yang diajukan oleh para pihak. Alat-alat bukti yang dikenal dalam hukum acara perdata diatur dalam Pasal 164/HIR/284 R.Bg. dan Pasal 1866 KUHPerdata adalah :
a. Alat bukti surat (tulisan)
b. Alat bukti saksi (witnesses);
c. Persangkaan (vermoeden);
d. Pengakuan (confession, bekentenis);
e. Sumpah (eed)

Selain alat-alat ukti tersebut, juga dikenal pemeriksaan setempat (descente) dan keterangan ahli (expertise) sebagai alat bukti, meskipun dalam HIR/R. Bg. Tidak secara tegas disebutkan bahwa kedua hal tersebut merupakan alat bukti atau perluasan dari alat bukti yang diatur dalam Pasal 164 HIR/284 R.Bg. akan tetapi, dengan melihat maksud pengaturan dan tujuan penerapannya, dapat dipahami bahwa keduanya dapat menjadi alat bukti yang selanjutnya dapat dipertimbangkan oleh majelis hakim.

\section{Diajukan Dalam Persidangan}

Prinsip dasar dalam pengajuan alat-alat bukti adalah diajukan dalam persidangan. Setiap alat bukti yang ingin diajukan oleh para pihak harus diajukan dalam persidangan. Tidak dibenarkan keterangan-keterangan saksi maupun pengakuan pihak tergugat yang dikemukakan di luar persidangan dianggap sebagai alat bukti yang sah, karena keabsahan suatu alat bukti, selain harus memenuhi syarat materill, juga harus memnuhi syarat formil, salah satunya adalah diajukan dalam persidangan. Pengecualian bagi ketentuan ini adalah pemeriksaan setempat 
(descente), karena proses untuk memperoleh data tidak mungkin dilakukan dalam persidangan, karena objek yang akan diperiksa mengenai letak, luas, batas dan sebagainya berada di luar persidangan. Pelaksanaan sidang pemeriksaan setempat harus dibuka di dalam ruang sidangdan selanjutnya diskors untuk melakukan pemeriksaan setempat. Penundaan siding untuk sidang berikutnya dapat dilakukan di tempat objek terperkara maupun di ruang siding. Laporan hasil pemeriksaan setempat tersebut akan dibacakan di dalam sidang berikutnya.

\section{Bertujuan untuk meyakinkan hakim}

Unsur terakhir, tetapi tidak kalah pentingnnya adalah motif atau tujuan mengajukan alat bukti, yaitu untuk meyakinkan hakim. Karena tujuannya untuk meyakinkan hakim, maka alat-alat bukti yang diajukan seharusnya berkaitan erat dengan pokok permasalahan yang sedang dihadapi, karena alat bukti yang tidak relevan tidak akan dipertimbangkan lebih lanjut oleh hakim.

Akta Perjanjian Pengikatan Jual Beli dapat dilakukan apabila pembeli belum mampu melunasi pembelian tersebut dan memberikan sejumlah uang yang dimiliki sebagai uang muka atau uang tanda jadi. Biasanya, calon pembeli melakukan perjanjian jual beli tersebut karena merasa tertarik dengan tanah tersebut, sesuai dengan fungsinya, Akta Perjanjian Pengikatan Jual Beli dapat juga dijadikan sebagai Bukti jika suatu saat terjadi sengketa baik melalui jalur litigasi maupun non litigasi. Dan alasan mengapa saya memilih topik mengenai Akta PPJB yaitu karena saya merasa Akta PPJB masih diragukan kekuatan Pembuktian nya dalam pemeriksaan suatu perkara, khususnya perkara yang didalam nya terdapat sengketa atau contentiosa. Padahal jelas-jelas bahwa Akta PPJB merupakan alat bukti tertulis, apalagi jika Akta PPJB tersebut dibuat dihadapan Pejabat Pembuat Akta Tanah (PPAT), yang otomatis Akta tersebut menjadi Akta Notaril yang mempunyai kekuatan pembuktian yang sempurna.

Sama halnya dengan studi kasus yang akan saya angkat sebagai penelitian ilmiah ini. Berhubungan dengan hal pembuktian, maka saya akan meneliti suatu studi kasus yang dimana telah terjadi perjanjian jual beli atas sebidang tanah seluas 12.000 
m2 yang dimana pembeli dan penjual bersepakat untuk mengadakan perjanjian pengikatan jual beli atas tanah tersebut. Tujuan diadakannya perjanjian pengikatan jual beli atas tanah tersebut adalah karena pembeli tidak mempunyai sejumlah uang sebesar Rp. 2.400.000.000,- (dua miliar empat ratus juta rupiah), melainkan pembeli hanya mempunyai uang sebanyak setengah dari sejumlah biaya dari tanah tersebut. Maka itulah pembeli menawarkan kepada penjual apakah bersedia jika diadakan Perjanjian pengikatan jual beli atas tanah yang dibuat dalam bentuk Akta Notarial tersebut dengan ketentuan-ketentuan yang tertera dalam Akta PPJB tersebut yang dimana dinyatakan bahwa penjual akan membayar secara bertahap pembelian atas tanah tersebut. namun ditengah-tengah perjanjian yang dibuat kedua belah pihak tersebut telah terjadi sengketa yang mengharuskan kedua belah pihak menyelesaikan perkaranya melalui jalur litigasi. Kasus lebih konkrit akan saya jabarkan di paragraf selanjutnya.

Kasus mengenai Pembuktian yang dimana telah terjadi kasus Pengadilan Tinggi yang telah keliru, salah menerapkan hukum pembuktian yang menginterpretasikan sendiri tanpa bukti-bukti otentik, (yang merupakan bukti sempurna) tidak memutuskan sesuai dengan pembuktian yang telah diajukan dalam persidangan, sehingga putusan a quo haruslah dibatalkan sesuai dengan Yurisprudensi Mahkamah Agung RI (Kasus Perkara Perdata antara PT. SALEMBARAN JATI MULYA dengan Tuan LIE TIN SON EFFENDI ) dimana dalam kasus tersebut terdapat kejanggalan dalam hal salah menerapkan hukum pembuktian. Kronologi Kasus Perkara Perdata antara PT. SALEMBARAN JATI MULYA dengan Tuan LIE TIN SON EFFENDI yaitu adalah pada sekitar pertengahan tahun 2001 tepatnya yaitu pada tanggal 5 September 2001 telah terjadi jual beli tanah Antara pihak pertama yaitu PT. SALEMBARAN JATI MULYA yang diwakili oleh Direktur, Tuan Yusuf Ngadiman dengan pihak kedua yaitu Tuan Lie Tin Son Effendi sebanyak 4 (empat) bidang tanah yang luas seluruhnya $12.000 \mathrm{~m} 2$ (dua belas ribu meter persegi). Bahwa atas bidang tanah yang masih girik yang akan dijual kepada pihak kedua maka akan dibuatkan akta perjanjian pengikatan jual beli dan sertifikatnya sedang dalam pengurusan 
permohonan Hak Guna Bangunan atas nama Pihak Pertama di kantor pertanahan Kabupaten Tangerang yang diperkirakan akan selesai selambat-lambatnya 3 bulan setelah dibuatnya akta perjanjian pengikatan jual beli tersebut. Bahwa selanjutnya atas kesepakatan bersama kedua belah pihak terhadap akta PPJB tersebut maka dibuatkan Akta Adendum yang isinya merubah ketentuan pembayaran atas jual beli tanah tersebut, sehingga isinya mengatur tentang pembayaran atas pembelian bidang tanah tersebut. Harga tanah tersebut secara keseluruhan adalah sebesar Rp. 2.400.000.000,- dan baru dibayarkan sebesar Rp. 1.380.000.000,- sehingga sisanya yaitu sebesar Rp. 1.020.000.000,-. Dan sisanya akan dibayar oleh pihak kedua kepada pihak pertama pada saat penanda tanganan akta jual beli atas tanah yang pada saat itu sedang diurus oleh pihak pertama dan apabila :

1. Sebagian dari tanah yang telah diperjanjikan tersebut yang mana letak, luas dan batas-batasnya telah diketahui dan disetujui oleh para pihak telah terbit sertifikatnya;

2. Telah dipenuhinya kewajiban pihak pertama yang telah disepakati para pihak dalam perjanjian ini yaitu pembuatan jalan masuk utama selebar 15 meter dan jalan samping kiri, kanan, depan dan belakan selebar 11 meter kesemuanya terbuat daric or beton dan saluran air dari lokasi yang diperjual belikan tersebut sampai ke sungai belakang telah selesai serta 1 pos keamanan yang terletak di jalan masuk utama.

Bahwa dalam akta addendum tersebut telah disepakati juga apabila pihak kedua belum membayar secara lunas seluruh biaya tanah tersebut maka pihak kedua hanya dapat mengambil 4 dari 8 sertifikat tersebut, dan sisa 4 sertifikat yang masih di simpan di kantor notaris baru dapat di ambil jika telah dilakukan pelunasan terhadap seluruh biaya tanah tersebut. Namun pada saat ditengah kesibukan pihak pertama membuat kewajibannya sesuai dengan akta addendum tersebut, pihak kedua telah menguasai seluruh sertifikat tanah dari bidang tanah yang dijual tersebut dan dikatakan bahwa pihak kedua telah membalik nama seluruh sertifikat tersebut dan sedangkan pihak kedua masih belum membayar lunas pembayaran harga tanah 
tersebut, dan hal tersebut sudah bisa di pastikan adalah perbuatan Wanprestasi. Dan akhirnya akibat dari hal tersebut pihak pertama menggugat pihak kedua ke Pengadilan Negri Tangerang dengan Nomor Putusan 340/PDT.G/2011/PN.TNG tanggal 13 Desember 2011 dan pada pengadilan tingkat pertama ini kasus dimenangkan oleh pihak pertama selaku penggugat, dan akhirnya untuk mencari suatu keadilan, maka pihak kedua mengajukan banding di pengadilan tinggi banten dengan Nomor Putusan 33/PDT/2012/PT.BTN tanggal 14 Juni 2012 dan pada pengadilan tingkat kedua ini dimenangkan oleh pihak kedua sebagai pembanding dan karena pihak pertama yang sebagai terbanding merasa bahwa dia tidak mendapatkan keadilan akhirnya pihak pertama selaku terbanding mengajukan kasasi di Mahkamah Agung dengan Nomor Putusan 3035 K/Pdt/2012 tanggal 18 Juli 2012, dan pada pengadilan tingkat kasasi ini, kasus di menangkan kembali oleh pihak kedua selaku termohon kasasi karena pihak kedua selaku termohon kasasi dapat membuktikan bahwa yang sebenarnya pada awalnya telah melakukan perbuatan Wanprestasi adalah Pihak pertama. Karena pihak penjual lah yang terlebih dahulu tidak melaksanakan kewajiban yang telah dijanjikan dalam Akta PPJB maka itu sudah dapat dipastikan bahwa yang pertama melakukan Wanprestasi adalah Pihak penjual. Namun karena pihak pertama selaku pemohon kasasi merasa bahwa dia masih belum puas terhadap putusan Mahkamah Agung maka pihak pertama kembali mangajukan Peninjauan Kembali di Mahkamah Agung dengan nomor putusan $124 \mathrm{PK} / \mathrm{Pdt} / 2015$ pada tanggal 25 Juni 2015 dan pada tingkat pengadilan paling akhir ini kasus kembali di menangkan oleh pihak kedua selaku termohon peninjauan kembali. Hal ini yang mendorong penulis untuk mengkaji Putusan Peninjauan Kembali dengan Nomor 124 PK/Pdt/2015 karena penulis beranggapan bahwa telah terjadi kekeliruan terhadap putusan PK ini, karena telah jelas-jelas dinyatakan dalam Akta PPJB bahwa jika pihak penjual tidak melaksanakan Kewajiban nya sesuai dengan yang diperjanjikan di dalam Akta PPJB, maka sisa pelunasan biaya tanah akan di anggap lunas karena pihak pembeli sendiri yang harus menyelesaikan kewajiban dari pihak penjual, dan biaya pelunasan tanah tersebut akan dipergunakan oleh pihak pembeli untuk 
menyelesaikan kewajiban dari pihak penjual. Namun pada kenyataan nya dalam putusan Kasasi, pihak pembeli tetap diharuskan untuk membayar sisa pelunasan biaya atas tanah yang telah dibeli nya tersebut, dan itu tidak sesuai dengan apa yang diperjanjikan di dalam Akta PPJB. Maka itu saya merasa bahwa Akta PPJB ini tidak mempunyai kekuatan pembuktian yang cukup kuat dalam pemeriksaan suatu persengketaan perdata dan tujuan saya mengambil topik ini adalah untuk mengetahui bagaimana seharusnya pertimbangan hakim dalam menilai kekuatan pembuktian pada akta otentik.

Maka Berdasarkan latar belakang di atas maka penulis tertarik untuk membuat skripsi dengan judul: "KEKUATAN PEMBUKTIAN AKTA NOTARIAL DALAM PENYELESAIAN PERKARA JUAL BELI TANAH (Studi Putusan No. 124 PK/Pdt/2015) “.

\section{B. Permasalahan}

Berdasarkan uraian latar belakang di atas, maka permaslaahan yang hendak dirumuskan adalah:

1. Bagaimana kekuatan pembuktian akta notarial dalam penyelesaian perkara jual beli tanah ? (Studi Putusan No. 124 PK/Pdt/2015)

\section{Metode Penelitian}

Metode penelitian hukum merupakan suatu proses untuk menemukan aturan hukum, prinsip-prinsip hukum, maupun doktrin-doktrin hukum guna menjawab isu hukum yang akan dihadapi.

\section{Tipe Penelitian}

Jenis penelitian hukum yang digunakan dalam penelitian ini adalah jenis penelitian hukum normatif menurut Soerjono Soekanto yaitu penelitian terhadap sistematik hukum. "Penelitian terhadap sistematik hukum dapat dilakukan pada perundang-undangan tertentu yang bertujuan untuk mengadakan identifikasi terhadap 
pengertian-pengertian pokok/dasar dalam hukum"4"Penelitian terhadap sistematik hukum adalah khusus terhadap bahan-bahan hukum primer dan sekunder"5.Jadi jika dikaitkan dengan penelitian ini maka peneliti mengidentifikasi pokok/dasar hukum yang berkaitan dengan masalah yang dibahas. Dasar-dasar hukum positif tersebut berkaitan dengan pertimbangan hakim dalam memberikan putusan dinilai dari kekuatan pembuktian Akta Perjanjian Pengikatan Jual Beli dalam penyelesaian perkara jual beli tanah Hak Guna Bangunan.

\section{Jenis dan Sumber Data}

"Penelitian hukum normatif menggunakan bahan pustaka yang digolongkan sebagai data sekunder"6.

\section{a. Bahan Hukum Primer}

Merupakan bahan-bahan hukum yang memiliki kekuatan mengikat terhadap masyarakat. Bahan hukum primer yang digunakan dalam penelitian ini yaitu Kitab Undang-undang Hukum Perdata, dan Undang-Undang Nomor 5 tahun 1960 tentang Peraturan Dasar Pokok-Pokok Agraria dan Peraturan Pemerintah Nomor 24 Tahun 1997 tentang Pendaftaran Tanah.

b. Bahan Hukum Sekunder

Bahan-bahan hukum yang diperoleh dari buku, teks, jurnal-jurnal asing, pendapat para sarjana, dan kasus-kasus hukum.

c. Bahan Non-Hukum

Bahan hukum yang memberikan petunjuk atau penjelasan bermakna terhadap bahan hukum primer atau sekunder seperti kamus, ensiklopedia, dan lain-lain.

\section{Pendekatan}

\footnotetext{
${ }^{4}$ Soerjono Soekanto dan Sri Mamudji, Op.Cit., hal. 15.

${ }^{5}$ Ibid., hal. 70 .

${ }^{6}$ Ibid., hal. 24.
} 
Prof. Peter Mahmud sendiri menggunakan istilah Pendekatan dibanding istilah Penelitian. Adapun pendekatan yang dilakukan adalah pendekatan kasus (case study).Dimana pendekatan kasus ini dilakukan dengan cara menelaah terhadap kasuskasus yang berkaitan dengan isu yang dihadapi yang telah mempunyai kekuatan hukum yang tetap ${ }^{7}$.

Dalam konteks studi kasus hukum, terdapat tiga tipe studi kasus hukum, yaitu ${ }^{8}$ :

a. Studi kasus non yudisial, yaitu studi kasus hukum tanpa konflik yang tidak melibatkan pengadilan.

b. Studi kasus yudisial, yaitu studi kasus hukum karena konflik yang diselesaikan melalui putusan pengadilan, disebut juga studi yurisprudensi.

c. Studi kasus hukum langsung, yaitu studi kasus hukum yang masih berlangsung dari awal hingga berakhirnya proses kasus tersebut.

Dipandang dari segi karateristik kasus yang menjadi objek penelitiannya, studi kasus hukum dapat digolongkan menjadi dua, yaitu'

a. Studi kasus tunggal, yang digunakan apabila kasus hukum yang banyak itu mempunyai kriteria atau karateristik yang sama sehingga cukup diambil satu kasus hukum saja.

b. Studi kasus ganda, yang digunakan apabila ada beberapa kasus hukum yang mempunyai kriteria yang berbeda sehingga perlu diambil semuakasus atau beberapa kasus yang mewakili kasus hukum yang sejenis secara purposive.

\section{Teknik Pengumpulan dan Pengolahan Data}

${ }^{7}$ Peter Mahmud Marzuki, Penelitian Hukum,Edisi Revisi (Jakarta: Kencana Prenada Media Group, 2011). 93

${ }^{8}$ Abdul Kadir Muhammad, dalam Frimanda Ginting, Perjanjian Kartel Unggas yang Diinisiasi oleh Pemerintah yang Diduga Melanggar Pasal 11 UU No. 5 Tahun 1999 dalam Putusan KPPU No. 02/KPPU-I/2016, Tesis MH Universitas Indonesia, Jakarta, 2016, hal. 19-

${ }^{9}$ Ibid.,hlm. 41 
Teknik Pengumpulan data yang digunakan dalam penulisan ini adalah Berdasarkan penguraian di atas, penulis memutuskan menggolongkan studi kasus hukum yang penulis lakukan dalam tipe studi kasus hukum yudisial dengan karakteristik studi kasus tunggal. Hal ini karena penulis menimbang bahwa fakta bahwa Putusan Banding Nomor 33/PDT/2012/PT.BTN adalah kasus yang cukup menarik terkait Kekuatan Pembuktian suatu Akta dalam penyelesaian perkara jual beli tanah Hak Guna Bangunan.

\section{Tenik Analisa Data}

Teknik telaah bahan hukum menggunakan cara deduktif yaitu dengan"menjelaskan suatu hal yang bersifat umum kemudian menariknya menjadi kesimpulan yang lebih khusus"10. Penggunaan metode deduktif berpangkal dari premis mayor (pernyataan yang bersifat umum), yang kemudian diajukan premis minor (bersifat khusus) dan dari kedua premis itu kemudian ditarik suatu kesimpulan atau conclusion. Akan tetapi di dalam argumentasi hukum, silogisme hukum tidak sesederhana silogisme tradisional.Langkah-langkah selanjutnya yang dipergunakan dalam melakukan suatu penelitian hukum, yaitu ${ }^{11}$ :

a. Mengidentifikasi fakta hukum dan mengeliminir hal-hal yang tidak relevan untuk menetapkan isu hukum yang hendak dipecahkan;

b. Pengumpulan bahan-bahan hukum dan sekiranya dipandang mempunyai relevansi juga bahan-bahan non-hukum;

c. Melakukan telaah atas isu hukum yang diajukan berdasarkan bahan-bahan yang telah dikumpulkan;

d. Menarik kesimpulan dalam bentuk argumentasi yang menjawab isu hukum;

\footnotetext{
${ }^{10}$ Jujun S.Suriasumantri, Filsafat Ilmu, Cetakan ke-3. (Jakarta: Pustaka Sinar Harapan, 1987),
} hal. 44

\footnotetext{
${ }^{11}$ Peter Mahmud Marzuki, Op.Cit., hal. 47.
} 
e. Memberikan preskripsi berdasarkan argumentasi yang telah dibangun di dalam kesimpulan.

\section{PEMBAHASAN}

\section{A. Hasil Penelitian}

1. Wawancara dengan Ibu Dinda Keumala, SH., M.Kn. selaku Notaris di Tangerang $^{12}$

Menurut ibu Dinda Keumala SH., M.Kn. memberikan pendapatnya bahwa kekuatan Perjanjian Pengikatan Jual Beli merupakan kekuatan pembuktian yang sah jika perjanjian tersebut telah disepakati oleh kedua belah pihak, karena menurut ibu Dinda Keumala SH., M.Kn. suatu perjanjian akan dianggap sah apabila telah dipenuhi nya syarat-syarat yang diatur dalam pasal 1320 Kitab Undang-undang hukum perdata

hukum perdata yaitu :

1. kesepakatan mereka yang mengikatkan dirinya;

2. kecakapan untuk membuat suatu perikatan;

3. suatu pokok persoalan tertentu;

4. suatu sebab yang tidak terlarang.

Karena menurut beliau semua kembali lagi kepada pasal 1320 Kitab Undangundang hukum perdata tersebut yaitu tentang syarat sahnya suatu perjanjian. Pasal 1870 KUHPerdata menyatakan bahwa suatu akta otentik merupakan bukti yang sempurna tentang apa yang dimuat didalamnya, tetapi menurut Pasal 1871 KUHPerdata menjelaskan bahwa suatu akta otentik namunlah tidak memberikan bukti yang sempurna tentang apa yang termuat didalamnya sebagai suatu penuturan belaka, jika yang termuat hanya sebagai penuturan belaka tidak ada hubungan langsung dengan pokok isi akta, maka itu hanya sebagai bukti permulaan dengan

${ }^{12}$ Dinda, Wawancara, dengan Notaris/PPAT, (Tangerang: Jalan Raden Fatah Nomor 63, RT. 1 / RW. 9, Sudimara Selatan, Ciledug, Kota Tangerang, 23 Mei 2018). 
tulisan. Jadi jika ditanyakan apakah Perjanjian Pengikatan Jual Beli yang dibuat dihadapan Notaris itu mempunyai kekuatan pembuktian yang sah atau tidak, maka jawabannya adalah maupun Perjanjian Pengikatan Jual Beli tersebut dibuat di hadapan Notaris atau pun mau dibuat secara bawah tangan antara pihak kesatu dan pihak kedua, maka kekuatan nya adalah sah-sah saja yang penting keduanya sepakat untuk membuat suatu perjanjian atas pembelian tanah tersebut.

Tentang addendum yang mengubah ketentuan pasal tentang pembayaran atas pembelian tanah di anggap sah secara hukum atau tidak, maka menurut ibu Dinda Keumala SH., M.Kn hal tersebut sah-sah saja karena menurut beliau hal tersebut kembali lagi kepada kesepakatan antara para pihak yang ada di perjanjian yang akan di addendum kan tersebut, dan selama para pihak setuju dan sepakat atas perubahan pasal tentang pembayaran atas pembelian tanah tersebut maka addendum tersebut sah-sah saja, namun dengan catatan maka pasal tentang pembayaran yang ada di perjanjian yang sebelumnya yaitu Perjanjian Pengikatan Jual Beli dianggap sudah tidak sah dan merujuk kepada pasal tentang pembayaran yang telah diganti yang tertuang di addendum tersebut, namun pasal-pasal lain yang ada di Perjanjian Pengikatan Jual Beli selain yang diubah tetap dianggap berlaku dan merupakan satu kesatuan dengan addendum tersebut.

Suatu addendum jika dibuat dihadapan Notaris, dan jika suatu saat terjadi sengketa antara pihak satu dan pihak dua, apakah notaris dapat dijadikan turut tergugat ?menurut ibu Dinda Keumala SH., M.Kn hal tersebut dapat dilihat ketentuannya di Undang-Undang Nomor 2 Tahun 2014 Tentang Perubahan Atas Undang-undang No. 30 Tahun 2004 Tentang Jabatan Notaris. Hal tersebut bisa saja notaris menjadi tergugat maupun terdakwa atau juga menjadi saksi dalam sengketa tersebut, tergantung dari apakah notaris tersebut dalam pembuatan akta notarial tersebut sudah sesuai atau belum dengan ketentuan yang ada pada Undang-Undang Nomor 2 Tahun 2014 Tentang Perubahan Atas Undang-undang No. 30 Tahun 2004 Tentang Jabatan Notaris. Contohnya saja jika akta yang dibuat oleh notaris namun 
jika penandatanganan tidak dilakukan dihadapan notaris, maka akta tersebut kekuatan nya hanyalah sebagai akta bawah tangan dan tidak lagi menjadi akta notarial karena tidak dilangsungkan penandatanganan aktanya di hadapan notaris yang membuat akta tersebut, ketentuan ini di atur dalam pasal 41 Undang-Undang Nomor 2 Tahun 2014 Tentang Perubahan Atas Undang-undang No. 30 Tahun 2004 Tentang Jabatan Notaris $^{13}$. Maka itu para pihak yang akan melakukan suatu perjanjian yang dibuat secara notarial harus memperhatikan hal ini, karena jika tidak memperhatikan hal ini akan merugikan kedua belah pihak.

2. Wawancara dengan Bapak Hanafi Tanawijaya, S.H., M.H., selaku Dosen Fakultas Hukum Universitas Tarumanagara dan Praktisi Hukum Tanah ${ }^{14}$

Menurut Bapak Hanafi Tanawijaya, S.H., M.H., memberikan pendapatnya bahwa Perjanjian Pengikatan Jual Beli merupakan suatu pembuktian yang sempurna bagi para pihak yang ada di dalam PPJB tersebut jika suatu saat terjadi sengketa atau menjadi bukti seandainya para pihak harus berperkara di Pengadilan. Dan bagaimana jika setelah dibuatnya Akta PPJB lalu dibuatlah addendum yang isinya mengubah ketentuan pasal tentang pembayaran atas pembelian tanah tersebut, lalu menurut Bapak Hanafi Tanawijaya, S.H., M.H tentang adanya addendum tersebut adalah bahwa sepanjang addendum tersebut di sepakati oleh para pihak dan kemudian mereka membuktikannya dengan bentuk paraf atau tanda tangan di dalam addendum itu maka sah-sah saja, karena addendum itu merupakan bagian yang tidak terpisahkan, maka kalaupun terjadi suatu perubahan, maka klausul yg dimaksud di dalam pasal-pasal yang ada, maka addeundum itu merupakan janji tambahan yg tidak terpisahkan atau menjadi satu kesatuan dengan PPJB yg telah dibuat sebelumnya, jadi pasal-pasal lain tetap sama dan tidak ada perubahan, karena yg di addendumkan

${ }^{13}$ Indonesia, Undang-Undang Nomor 2 Tahun 2014 Tentang Perubahan Atas Undang-Undang No. 30 Tahun 2004 Tentang Jabatan Notaris (Lembaran Negara Republik Indonesia Tahun 2014 Nomor 3, Tambahan Lembaran Negara Republik Indonesia Nomor 5491), Pasal 41.

${ }^{14}$ Hanafi Tanawijaya, Wawancara, dengan Dosen Fakultas Hukum Universitas Tarumanagara dan Praktisi Hukum Tanah, (Jakarta: Universitas Tarumanagara, Jalan Letjen S. Parman No. 1, 11440, 06 Juni 2018). 
hanya pasal-pasal tertentu, tetapi otomatis pasal yang telah di addendumkan tersebut dianggap telah tidak berlaku lagi karena telah di addendumkan, tetapi pasal-pasal yang lain tetap melekat antara PPJB dan Addendum.

Jika addendum tersebut dibuat dihadapan Notaris dan jika suatu saat terjadi sengketa, apakah notaris dapat dijadikan turut tergugat atau hanya sebagai saksi? lalu Bapak Hanafi Tanawijaya, S.H., M.H memberikan pendapatnya bahwa notaris itu pada dasarnya hanya membuat perjanjian apapun hanya berdasarkan surat formal yang disampaikan kepada notaris tersebut, dan yang menghadap adalah para pihak, jadi sebenarnya dia tidak bertanggungjawab terhadap isi yang ada di dalam akta tersebut, karena isi akta itu adalah kesepahaman dari mereka para pihak, makanya dibacakan, dan sebenarnya seorang notaris bisa saja digugat, jika akta itu terjadi kesalahan atau maladministrasi atau terjadi rekayasa, tidak hanya bs digugat namun notaris bisa juga di jadikan tersangka atau saksi, jadi kemungkinan nya banyak tergantung dari urgensi nya produk apa yang dihasilkan dari notaris tersebut, kalau akta itu menyesatkan dimana notaris membuat rekayasa dan terjadi suatu konspirasi jahat maka sangat mungkin dia bisa dijadikan minimal menjadi tersangka, tergugat, atau saksi.

Berbicara mengenai bagaimana jika pada saat penandatanganan akta tersebut tidak dilakukan dihadapan notaris, melainkan dilakukan dihadapan asisten dari notaris tersebut, lalu Bapak Hanafi Tanawijaya, S.H., M.H memberikan pendapatnya bahwa hal tersebut tidak boleh terjadi, karena setiap produk akta yg dibuat oleh notaris, maka harus dilakukan dihadapan notaris, dan perihal jika notaris yang menghampiri klien nya hal itu juga tidak boleh dilakukan jika menurut kode etik dari seorang notaris hal itu diatur diUndang-Undang Nomor 2 Tahun 2014 Tentang Perubahan Atas Undang-undang No. 30 Tahun 2004 Tentang Jabatan Notaris. Karena yang seharusnya adalah para pihak yang menghadap notaris. Dan jika sampai hal tersebut terjadi, sanksi nya tidak langsung batal demi hukum, melainkan trgantung putuann pengadilan, namun dalam sisi administrasi dan proses perbuatan nya ada 
suatu kesalahan, karena seharusnya para pihak yang menghadap notaris, bukan notaris yang menghampiri para pihak, karena jika sampai hal tersebut terjadi maka notaris tersebut telah melanggar jabatan notaris dan kode etik dari notaris, tetapi hal tersebut tidak membuat kekuatan pembuktian akta Notarial tersebut menjadi hilang, karena sumber kekuatan pembuktian dari Akta Notarial tersebut adalah perjanjian yang disepakati dan disetujui oleh para pihak yang membuat perjanjian tersebut. Kecuali para pihak yang membuat perjanjian tersebut membatalkan perjanjian yang telah mereka buat sebelumnya.

\section{B. Analisa}

Pembuktian pada dasarnya merupakan hal yang wajib dalam pemeriksaan suatu perkara, khususnya perkara yang didalam nya terdapat sengketa atau contentiosa. Jika dalam pemeriksaan suatu sengketa perdata, para pihak berbeda pendapat atau pendirian dan masing-masing ingin meneguhkan dalil-dalilnya, maka pada saat itulah dibutuhkan pembuktian untuk meyakinkan hakim pihak mana yang benar atau mempunyai hak dan pihak mana yang salah atau tidak mempunyai hak.

Urgensi pembuktian merupakan jargon yang penulis ajukan sebagai representasi dari pentingnya upaya pembuktian serta tujuan ideal yang ingin dicapai dari suatu pembuktian. Urgensi pembuktian dalam pemeriksaan perkara perdata merujuk pada definisi dari pembuktian itu sendiri, pembuktian oleh berbagai pakar didefinisikan dengan redaksi yang berbeda-beda. Meskipun demikian, dari perbedaan definisi tersebut, dapat dipahami bahwa pembuktian pada dasarnya merupakan upaya yang dilakukan oleh pihak-pihak yang bersengketa dalam menghadirkan alat-alat bukti tertentu dalam persidangan untuk meyakinkan hakim. 
Dengan memperhatikan pokok-pokok permasalahan dalam pendahuluan, maka dapat dikemukan beberapa analisis penulis yang terkait dengan kekuatan pembuktian akta notarial dalam penyelesaian perkara jual beli tanah sebagai berikut :

\section{a. Kekuatan Pembuktian Akta Notariil dalam Penyelesaian Perkara Jual Beli Tanah}

Mengenai kekuatan pembuktian akta notaril dalam penyelesaian perkara Jual Beli Tanah, sebenarnya akta notaril merupakan akta yang mempunyai kekuatan hukum yang sempurna atau tidak dapat dibantahkan selama sesuai dengan prosedur yaitu dibuat dan dibacakan serta ditandatangani di depan notaris, isi akta merupakan keinginan para pihak tapi sebagai pejabat umum notaris bertanggung jawab penuh atas isi akta tersebut mengenai kebenaran dan ketentuan-ketentuan yang ada di dalamnya, menjamin tanggal dan orang/pihak yang menandatanganinya adalah orang yang cakap dan berwenang. Berbeda dengan akta yg di legalisasi, Akta yang di Legalisasi adalah akta yang biasa dibuat di bawah tangan (isinya bukan dibuat oleh Notaris walaupun pada prakteknya Notaris yang punya draf atau yang mengetikkan dan mencetaknya) yang dibawa dan dibacakan/dijelaskan serta ditandatangani di depan Notaris dan kemudian dicatatkan dalam buku daftar dengan memberi nomor. Dalam hal ini Notaris tidak bertanggungjawab terhadap isi aktanya, Notaris hanya menjamin tanggal dan orang/pihak yang menandatanganinya adalah orang yang cakap dan berwenang.

\section{b. Putusan PK yang Merugikan Pihak Pembeli Tanah}

Berkenaan dengan Akta Notariil maka itu penulis ingin melakukan suatu penelitian terhadap kekuatan pembuktian dari akta notariil tersebut yang digunakan sebagai alat bukti dalam penyelesaian sengketa jual beli tanah pada Putusan Mahkamah Agung Nomor 124 PK/Pdt/2015. Karena menurut penulis putusan ini merupakan suatu putusan yang merugikan pihak pembeli selaku Termohon Peninjauan Kembali, karena dalam putusan PK ini pembeli tetap di suruh membayar pelunasan sisa harga tanah yang dibeli nya dari pembeli oleh 
majelis hakim, padahal jelas-jelas di nyatakan pada akta addendum yang merubah pasal tentang tata cara pembayaran pada Akta Perjanjian Pengikatan Jual Beli yang dikatakan bahwa sisa pembayaran yang belum dibayarkan oleh pihak pembeli kepada pihak penjual pada saat penanda tanganan akta jual beli atas tanah yang pada saat itu sedang diurus oleh pihak pertama dan apabila :

1. Sebagian dari tanah yang telah diperjanjikan tersebut yang mana letak, luas dan batas-batasnya telah diketahui dan disetujui oleh para pihak telah terbit sertifikatnya;

2. Telah dipenuhinya kewajiban pihak pertama yang telah disepakati para pihak dalam perjanjian ini yaitu pembuatan jalan masuk utama selebar 15 meter dan jalan samping kiri, kanan, depan dan belakan selebar 11 meter kesemuanya terbuat daric or beton dan saluran air dari lokasi yang diperjual belikan tersebut sampai ke sungai belakang telah selesai serta 1 pos keamanan yang terletak di jalan masuk utama.

Namun pada kenyataannya putusan majelis hakim berkata lain karena apa yang telah dicantumkan pada Akta Addendum yang merubah isi pasal tentang tata cara pembayaran pada Akta Perjanjian Pengikatan Jual Beli tidak di gubris sama sekali dan akhirnya pihak pembeli dari tanah tersebut tetap disuruh untuk melakukan pelunasan sisa pembayaran yaitu sebesar Rp. 1.020.000.000,- dari total yang telah dibayarkan oleh pihak pembeli kepada pihak penjual sebesar Rp. 1.380.000.000,-. Padahal pihak penjual mempunyai satu kewajiban yang belum dilaksanakan nya hingga saat ini yaitu pembuatan jalan masuk utama selebar 15 meter dan jalan samping kiri, kanan, depan dan belakan selebar 11 meter kesemuanya terbuat daric or beton dan saluran air dari lokasi yang diperjual belikan tersebut sampai ke sungai belakang telah selesai serta 1 pos keamanan yang terletak di jalan masuk utama. Yang pada akhirnya pihak pembeli sendiri lah yang harus menyelesaikan kewajiban dari pihak penjual tersebut. dan menurut saya putusan Peninjauan Kembali ini merugikan pihak 
pembeli tanah tersebut, karena hakim tidak memperhatikan alat bukti yang dimiliki oleh para pihak yaitu Akta Perjanjian Pengikatan Jual beli dan Akta Addendum yang merubah tentang tata cara pembayaran dalam Akta PPJB tersebut.

\section{c. Kekuatan Akta Notariil Menjadi Akta Bawah Tangan}

Berdasarkan hasil wawancara dengan Notaris Dinda Keumala S.H., M.Kn. dinyatakan bahwa kekuatan pembuktian dari suatu akta notaril tergantung dari prosedur dalam pembuatan akta tersebut, karena semua nya harus bergantung pada Undang-undang nomor 30 tahun 2004 Juncto Undangundang nomor 2 tahun 2014 tentang Jabatan Notaris, dikatakan bahwa jika suatu akta yang dibuat Notaris namun jika tidak dibacakan dan tidak di tandatangani di hadapan notaris maka hasilnya akta tersebut akan berkekuatan menjadi akta bawah tangan. Maka hal itu akan merugikan para pihak bagi yang tidak mengerti apa makna dari Akta Notaris. Karena sesuai dengan pasal 1 angka (7) Undang-undang nomor 30 tahun 2004, Akta Notaris adalah akta otentik yang dibuat oleh atau dihadapan notaris menurut bentuk dan tata cara yang ditetapkan dalam Undang-undang ini $^{15}$.

Menurut saya apa yang dijelaskan oleh Notaris Dinda Keumala S.H., M.Kn. masuk akal, karena Notaris Dinda Keumala tidak berpihak pada salah satu pihak karena Notaris Dinda Keumala hanya bersikap Netral terhadap kasus penyelesaian sengketa jual beli tanah ini dan apa yang dikatakan mengenai kekuatan Akta Notariil dapat menjadi Akta Bawah Tangan jika suatu akta yang dibuat Notaris namun jika tidak dibacakan dan tidak di tandatangani di hadapan notaris maka hasilnya akta tersebut akan berkekuatan menjadi akta bawah tangan juga merupakan hal yang masuk akal jika pada kenyataannya Akta tersebut tidak dibacakan dan tidak ditandatangani di hadapan notaris tersebut.

\footnotetext{
${ }^{15}$ Indonesia, Undang-Undang Nomor 30 Tahun 2004 tentang Jabatan Notaris, Pasal 1 Angka 7.
} 


\section{d. Akta Merupakan Kekuatan Pembuktian Sempurna}

Jika dilihat dari teori kekuatan pembuktian akta, Akta merupakan kekuatan pembuktian sempurna, karena akta merupakan kekuatan yang memberikan kepastian yang cukup kepada hakim. Jadi, dalam hal ini bilamana akta tersebut digunakan sebagai alat bukti dan akta ini berisi perjanjian jual beli, pihak pengunggat telah berhasil membuktikan dengan akta tersebut bahwa benar ada perjanjian jual beli antara pengunggat dan tergugat. Dan bila tergugat menyangkali kebenaran itu, tergugatlah yang dibebani pembuktian untuk membuktikan tidak adanya perjanjian. Yang penting digaris bawahi dalam hal kekuatan pembuktian sempurna ini adalah alat bukti sudah tidak perlu di lengkapi dengan alat bukti lain, tetapi masih memungkinkan pembuktian lawan. Dalam hal akta notaris, jika pada minut yang disimpan oleh notaris terdapat tanda tangan palsu dan perihal kepalsuan tanda tangan tersebut dapat dibuktikan, maka gugurlah kekuatan pembuktian dari akta notariil tersebut. Kekuatan pembuktian sempurna itu, juga memiliki daya berlaku yang terbatas, sebagai contoh: kekuatan pembuktian sempurna dari akta autentik yang bersifat akta partij itu hanya berlaku bagi kedua pihak atau ahli warisnya serta orangorang yang memperoleh hak dari mereka. Terhadap pihak ketiga, kekuatan pembuktian sempurna dari suatu akta autentik adalah tidak berlaku. Dari suatu akta autentik, kekuatan yang berlaku bagi pihak ketiga hanyalah kekuatan pembuktian bebas,artinya kekuatan diserahkan kepada pertimbangan hakim sepenuhnya. Sesuai dengan apa yang dikatakan oleh Bapak Hanafi Tanawijaya, S.H., M.H., yang memberikan pendapatnya bahwa Perjanjian Pengikatan Jual Beli merupakan suatu pembuktian yang sempurna bagi para pihak yang ada di dalam PPJB tersebut jika suatu saat terjadi sengketa atau menjadi bukti seandainya para pihak harus berperkara di Pengadilan. 


\section{III. $\mid$ PENUTUP}

Penulis dalam bab ini akan memaparkan kesimpulan sebagai jawaban atas permasalahan yang ada pada bab-bab terdahulu serta saran yang merupakan rekomendasi kepada ilmu pengetahuan dalam bidang hukum, khususnya di bidang hukum tanah dan hukum perjanjian

\section{A. Kesimpulan}

Berdasarkan hasil penelitian sebagaimana diuraikan pada bab-bab sebelumnya, Penulis menyimpulkan bahwa telah terjadi kesalahan dan keliru dalam menerapkan hukum serta tidak melaksanakan hukum sebagaimana mestinya, karena pertimbangan-pertimbangan hukum nya tidak sesuai dengan fakta-fakta hukum seperti penilaian yang keliru terhadap alat-alat bukti dan lagi pula pertimbanganpertimbangan hukum nya tidak mencerminkan keadilan bagi pihak pembeli tanah, karena apa yang telah tertulis di addendum pada akhirnya tidak digunakan oleh hakim untuk memutus perkara ini, sesuai dengan apa yang diputus oleh hakim dalam Putusan Kasasi Nomor 3035 K/Pdt/2012 bahwa pembeli tanah tetap harus melakukan pelunasan sisa harga tanah yang dibeli nya dari penjual sebesar Rp. 677.000.000,(enam ratus tujuh puluh tujuh juta rupiah). Hal tersebut telah membuat bahwa kekuatan pembuktian dari akta notarial dalam hal ini akta addendum tidak mempunyai kekuatan pembuktian yang kuat atau sempurna. Karena jelas-jelas apa yang telah tercantum di akta addendum bahwa jika penjual terlebih dahulu tidak melakukan kewajibannya sesuai dengan waktu yang telah diperjanjikan antara kedua belah pihak atau jika terjadi Wanprestasi, maka sisa pelunasan biaya pembelian tanah akan dianggap lunas karena pihak pembeli sendiri yang harus menyelesaikan kewajiban yang seharusnya di selesaikan oleh pihak penjual. Tentu saja hal tersebut sudah sangat merugikan pihak pembeli ditambah putusan kasasi yang menambah kerugian dari pihak pembeli.

\section{B. Saran}


Penulis memberikan beberapa saran yang sekiranya dapat dijadikan sebagai pertimbangan dalam hal terjadinya sengketa tanah. Adapun saran tersebut diberikan untuk menjamin terpenuhinya kepastian hukum bagi para pihak.

1. Bagi penegak hukum, sengketa dalam kasus pertanahan yang ada di dalam masyarakat merupakan hal yang wajar terjadi, karena dalam kasus jual beli tanah, sengketa sangat mungkin terjadi antara pihak penjual dan pihak pembeli, maka itu diperlukan penegak hukum yang dalam kasus ini adalah hakim untuk :

a. lebih adil dalam memutus suatu perkara;

b. hakim lebih menyisihkan waktunya untuk mempelajari pengetahuan hukum tentang perkara yang sedang ditangani agar terhindar dari terjadinya hakim yang kurang mengetahui pengetahuan terhadap perkara yang sedang ditanganinya;

c. hakim seharusnya dibatasi kuotanya dalam menangani kasus perkara di pengadilan, tujuannya yaitu agar hakim memiliki cukup waktu untuk menuliskan semua argumen hukum secara lengkap;

d. hakim seharusnya lebih meningkatkan pengetahuan dan wawasannya, sehingga hal tersebut berpengaruh terhadap kualitas putusan yang dibuat olehnya.

2. berdasarkan putusan hakim dalam kasus Putusan Nomor 124 PK/Pdt/2015, hakim dalam menangani perkara ini dianggap kurang memahami pengetahuan hukum tentang perkara yang sedang ditanganinya, sehingga terjadi kekeliruan dalam memberikan putusan yang pada akhirnya merugikan salah satu pihak, yaitu pihak pembeli. Namun secara normatif seharusnya hal ini tidak boleh terjadi, karena Hakim dapat memerintahkan setiap pihak untuk menyediakan ahli yang akan memberikan keterangan dan menjelaskan pokok persoalannya di dalam persidangan. Maka itu dibutuhkan hakim yang lebih mengerti terhadap perkara yang sedang di tanganinya. 


\section{DAFTAR PUSTAKA}

\section{A. Buku}

Harsono, Boedi. Hukum Agraria Indonesia. Jakarta: Universitas Trisakti, 2013

Harahap, Yahya, Hukum Acara Perdata tentang Gugatan, Persidangan, Penyitaan, Pembuktian, dan Putusan Pengadilan, Jakarta: Sinar Grafika, 2010.

Soekanto,Soerjono dan Sri Mamudji Penelitian Hukum Normatif. Jakarta: PT Rajagrafindo Persada, 2006

Mahmud,Peter Marzuki, Penelitian Hukum,Edisi Revisi Jakarta: Kencana Prenada Media Group, 2011

Kadir,Abdul Muhammad, dalam Frimanda Ginting, Perjanjian Kartel Unggas yang Diinisiasi oleh Pemerintah yang Diduga Melanggar Pasal $11 \mathrm{UU}$ No. 5 Tahun 1999 dalam Putusan KPPU No. 02/KPPU-I/2016, Tesis MH Universitas Indonesia, Jakarta, 2016

Jujun, S.Suriasumantri, Filsafat Ilmu. Jakarta: Pustaka Sinar Harapan, 1987

\section{B. Wawancara}

Dinda, Wawancara, dengan Notaris/PPAT, Tangerang: Jalan Raden Fatah Nomor 63, RT. 1 / RW. 9, Sudimara Selatan, Ciledug, Kota Tangerang, 23 Mei 2018

Tanawijaya, Hanafi, Wawancara, dengan Dosen Fakultas Hukum Universitas Tarumanagara dan Praktisi Hukum Tanah, Jakarta: Universitas Tarumanagara, Jalan Letjen S. Parman No. 1, 11440, 06 Juni 2018

\section{Peraturan Perundang-undangan}

Indonesia. Undang-Undang Dasar Negara Indonesia Tahun 1945. . Undang-Undang Nomor 5 Tahun 1960 Tentang Peraturan Dasar

Pokok-Pokok Agraria (Lembaran Negara Republik Indonesia Tahun 1960 Nomor 104, Tambahan Lembaran Negara Republik Indonesia Nomor 2043). 
Indonesia.Undang-undang Nomor 2 Tahun 2014 tentang Jabatan Notaris

(Lembaran Negara Republik Indonesia Tahun 2014 Nomor 3, Tambahan Lembaran Negara Republik Indonesia Nomor 5491). 